\title{
AN INVESTIGATION OF ENZYMES AND HORMONE- BINDING PROTEINS IN THE LUMINAL FLUID OF THE BOVINE UTERUS
}

\author{
G. P. ROBERTS* AND J. M. PARKER \\ Agricultural Research Council, Institute for Research on Animal Diseases, \\ Compton, Newbury, Berkshire
}

(Received 24th September 1973)

\begin{abstract}
Summary. Saline flushings from the uterine horns of cows in different stages of early pregnancy were examined for a number of enzymes and hormone-binding activities. The activities of several glycosidases were elevated when compared with serum; $\beta$-N-acetylglucosaminidase, $\beta$-N-acetylgalactosaminidase and $\alpha$-fucosidase were particularly active. The activities of some of these glycosidases increased with duration of pregnancy up to 21 days. No proteinase or neuraminidase activity was detected and the antitrypsin activity was similar to, or lower than, the values observed in serum. No progesterone or oestrogen-binding activity was detected in the flushings. The possible biological implications of the glycosidases in early embryonic development and implantation are discussed.
\end{abstract}

\section{INTRODUCTION}

The uterine luminal fluid is the medium in which a number of important events in the reproductive process take place. In addition to maturation processes such as capacitation of spermatozoa, this fluid provides the medium in which the early embryo develops. In the cow, the embryo lies free in the medium for 30 days or more during which time extensive embryonic differentiation takes place before the conceptus becomes firmly attached to the uterine wall. It has been shown by embryo transplant experiments (Rowson, Lawson, Moor \& Baker, 1972) that there is a strict synchrony requirement between donor and recipient during this time, suggesting that this medium has a constantly changing composition. In the rabbit, a protein named blastokinin or uteroglobulin has been reported to influence blastocyst formation from morulae (Krishnan \& Daniel, 1967) whilst in mouse uterine fluid a factor has been reported to be present which initiates implantation (Mintz, 1971).

In another paper (Roberts \& Parker, 1974) we have described the protein composition of the luminal fluid from the bovine uterus. In this paper, we report on certain enzymes in this fluid and on the hormone-binding activity of the macromolecular components of the fluid.

* Present address: Department of Surgery, Welsh National School of Medicine, Gardiff GF4 4XN. 


\section{MATERIALS AND METHODS}

\section{Materials}

The substrates, $\mathrm{p}$-nitrophenyl- $\alpha$-L-fucopyranoside, $\mathrm{p}$-nitrophenyl- $\beta$-Lfucopyranoside, $\mathrm{p}$-nitrophenyl- $\alpha$-D-galactopyranoside, $\mathrm{p}$-nitrophenyl- $\beta$-D-galactopyranoside, $\mathrm{p}$-nitrophenyl- $\alpha$-D-glucopyranoside, $\mathrm{p}$-nitrophenyl- $\beta$-D-glucopyranoside, $\mathrm{p}$-nitrophenyl-2-acetamido-2-deoxy- $\beta$-D-galactopyranoside, $\mathrm{p}$ nitrophenyl-2-acetamido-2-deoxy- $\beta$-D-glucopyranoside, $\quad$-nitrophenyl- $\alpha$-Dmannopyranoside and $\mathrm{p}$-nitrophenyl- $\beta$-D-mannopyranoside, were purchased from Koch-Light Laboratories Ltd, Colnbrook, Bucks. $\left[6,7-{ }^{3} \mathrm{H}\right]$ Oestradiol $(>40,000 \mathrm{mCi} / \mathrm{mol})$ and $\left[1,2,6,7-{ }^{3} \mathrm{H}\right]$ progesterone $(80,000$ to $110,000 \mathrm{mCi} / \mathrm{mol})$ were supplied by the Radiochemical Centre, Amersham. Crystalline trypsin (7500 to 8000 BAEE unit/mg) was obtained from BDH Chemicals Ltd, Poole, Dorset, and soybean trypsin inhibitor from Koch-Light Laboratories Ltd. Ovine submaxillary gland glycoprotein was prepared by the method of Heimer \& Meyer (1956).

Saline washings of the uteri of slaughtered cows and rabbits were obtained and the uterine proteins were prepared as described previously (Roberts \& Parker, 1974).

\section{Enzyme assays}

The enzymes, $\alpha$-L-fucosidase, $\beta$-L-fucosidase, $\alpha$-D-galactosidase, $\beta$-D-galactosidase, $\alpha$-D-glucosidase, $\beta$-D-glucosidase, $\beta$ - $\mathrm{N}$-acetylgalactosaminidase, $\beta$-Nacetylglucosaminidase, $\alpha$-D-mannosidase and $\beta$-D-mannosidase, were assayed by incubating 10 to $400 \mu \mathrm{g}$ uterine proteins in 10,20 to $40 \mu \mathrm{l}$ of $0 \cdot 15 \mathrm{M}$-saline with $200 \mu \mathrm{l}$ of a $5 \mathrm{~mm}$-solution of the corresponding p-nitrophenyl glycoside and $400 \mu \mathrm{l}$ of $0 \cdot 2 \mathrm{M}$-sodium phosphate $/ 0 \cdot 1 \mathrm{~m}$-citric acid buffer, $\mathrm{pH} 5 \cdot 0$. Incubations were carried out at $37^{\circ} \mathrm{C}$ and terminated after $3 \mathrm{hr}$ by the addition of $1.0 \mathrm{ml}$ of $0.25 \mathrm{~N}$-sodium carbonate. The resulting yellow colour was measured immediately at $420 \mathrm{~nm}$ in a Unicam SP1800 spectrophotometer. Enzymatic activity was expressed as $\mu \mathrm{g}$ p-nitrophenol released per $\mathrm{mg}$ of protein in $3 \mathrm{hr}$.

Neuraminidase activity was measured by incubating $200 \mu \mathrm{g}$ uterine proteins with $200 \mu \mathrm{g}$ ovine submaxillary gland glycoprotein in $200 \mu \mathrm{l}$ of $0.2 \mathrm{M}$-sodium acetate buffer, $\mathrm{pH} 5 \cdot 6$, containing $0 \cdot 1 \%$ calcium chloride and saturated with chloroform to prevent bacterial growth. After incubation for $16 \mathrm{hr}$ at $37^{\circ} \mathrm{C}$, the neuraminic acid released was assayed using thiobarbituric acid (Warren, 1959). Trypsin-like activity was measured using N-benzoyl-L-arginine methyl ester as substrate according to the method of Schwert \& Takenaka (1955). Inhibition of trypsin-like activity was measured by addition of the test material $(400 \mu \mathrm{g})$ to trypsin $(5 \mu \mathrm{g})$ and incubating for 0 and $30 \mathrm{~min}$ at room temperature before assay for trypsin-like activity as above.

The trypsin-like activity was also measured with a film gelatin lysis technique (Anderer \& Hoernle, 1968) using an Ilford R.30 Trichrome plate. The plate was developed, washed, and dried and single droplets of test solution were then placed on the gelatin and incubated for $16 \mathrm{hr}$ at room temperature in a moist atmosphere. The areas of lysis were detected after washing the plate in water. 


\section{Hormone-binding assays}

Proteins binding oestradiol or progesterone in the uterine proteins were assayed according to a modification of the method of Corker \& Exley (1970). The uterine proteins (200 $\mu \mathrm{g}$ in $20 \mu \mathrm{l}$ water) were incubated at $4^{\circ} \mathrm{C}$ with $200 \mu \mathrm{l}$ $0.01 \mathrm{M}$-tris-HGl buffer, $\mathrm{pH} 8.0$, containing $0.001 \mathrm{M}$-EDTA, $0.25 \mathrm{~m}$-sucrose and about $10,000 \mathrm{ct} / \mathrm{min}$ of $\left[6,7-{ }^{3} \mathrm{H}\right]$ oestradiol or $\left[1,2,6,7-{ }^{3} \mathrm{H}\right]$ progesterone. After incubation for $16 \mathrm{hr}, 1 \mathrm{ml}$ of a suspension of $0.25 \%$ Norit A (Sigma Chemical Co., Norbiton Station Yard, Kingston upon Thames, Surrey) and 0.0025\% Dextran T40 (Pharmacia GB Ltd, Sinclair House, The Avenue, West Ealing,

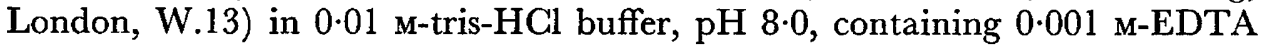
and $0.25 \mathrm{M}$-sucrose was added. After mixing and allowing to stand at $4^{\circ} \mathrm{C}$ for $15 \mathrm{~min}$, the suspension was centrifuged at $1874 \mathrm{~g}$ and $4^{\circ} \mathrm{C}$ for $15 \mathrm{~min}$. Aliquots $(1 \mathrm{ml})$ of the supernatants were added to $10 \mathrm{ml}$ scintillation fluid prepared according to Bray (1960) and counted in a Beckman CPM-100 liquid scintillation counter.

\section{RESULTS}

\section{Glycosidase assays}

The results of the glycosidase assays on the bovine uterine proteins are shown in Table 1. The values of the individual glycosidase activities, expressed as $\mu \mathrm{g}$ p-nitrophenol released per $\mathrm{mg}$ protein in $3 \mathrm{hr}$, were combined into groups for cows which were 0 to 3 (or 0 to 7 ), 5 to 7,13 to 15 and 19 to 21 days pregnant and since a wide range of values were obtained within the groups, these were analysed statistically. A log transformation was used on the data and the pooled estimate of variance was calculated for the transformed data. The significance tests were calculated using the 'least significance difference' technique with the pooled estimates of variance (Steel \& Torrie, 1960). The means quoted in Table 1 are therefore the geometric means and the $95 \%$ confidence intervals for all the means were calculated using the pooled estimates of variance.

$\alpha$-L-Fucosidase. The assay levels in all the uterine fluid samples were elevated compared to those in serum. When comparing the means of samples from cows at all three time periods ( 5 to 7,13 to 15 and 19 to 21 days), these were significantly higher $(P<0.01)$ than that of samples taken in the initial time period ( 0 to 3 days). There was also a significant increase $(P<0 \cdot 01)$ in the mean of the 13 to 15-day group compared with that of the 5 to 7 -day group.

$\beta$-L-Fucosidase. There were no significant differences between the assay levels in the uterine fluid samples of different time groups and serum.

$\alpha$-D-Galactosidase. The assay levels in all the uterine fluid samples were elevated compared with those in serum. A significant increase $(P<0 \cdot 01)$ was observed when levels in the 19 to 21-day animals was compared with those in the 0 to 7 -day group.

$\beta$-D-Galactosidase. The assay levels in all the uterine fluid samples were elevated compared with those in serum. Within the groups, there was a significant increase after 5 to 7 days which was continued into the 19 to 21-day period.

$\alpha-\mathrm{D}-$ Glucosidase. The assay levels in all the uterine fluid samples were elevated compared with those in serum. The means appeared to show an increase with 
Table 1. Glycosidase activities of proteins from the uterine luminal fluid and serum of the pregnant cow at various times after mating

\begin{tabular}{|c|c|c|c|}
\hline \multirow{2}{*}{$\begin{array}{l}\text { Glycosidase and } \\
\text { sample group }\end{array}$} & \multirow{2}{*}{$\begin{array}{c}\text { No. of } \\
\text { cows/group }\end{array}$} & \multicolumn{2}{|c|}{$\begin{array}{c}\text { Enzymatic activity } \\
\text { ( } \mu \text { g p-nitrophenol } \\
\text { released/mg protein } / 3 \text { hr) }\end{array}$} \\
\hline & & Mean & $\begin{array}{l}95 \% \text { confidence } \\
\text { interval for mean }\end{array}$ \\
\hline $\begin{array}{l}\alpha \text {-L-Fucosidase } \\
\text { Serum* } \\
\text { Day } 0 \text { to } 3 \\
\text { Day } 5 \text { to } 7 \\
\text { Day } 13 \text { to } 15 \\
\text { Day } 19 \text { to } 21\end{array}$ & $\begin{array}{l}5 \\
4 \\
8 \\
8 \\
4\end{array}$ & $\begin{array}{c}0 \cdot 3 \\
9 \\
31 \\
202 \\
66\end{array}$ & $\begin{array}{r}0 \cdot 1 \text { to } 0 \cdot 5 \\
4 \text { to } 19 \\
18 \text { to } 52 \\
121 \text { to } 338 \\
32 \text { to } 136\end{array}$ \\
\hline $\begin{array}{l}\beta \text {-L-Fucosidase } \\
\text { Serum } \\
\text { Day } 0 \text { to } 7 \\
\text { Day } 13 \text { to } 15 \\
\text { Day } 19 \text { to } 21\end{array}$ & $\begin{array}{l}3 \\
7 \\
7 \\
3\end{array}$ & $\begin{array}{l}0 \cdot 3 \\
1 \cdot 2 \\
0 \cdot 6 \\
2 \cdot 5\end{array}$ & $\begin{array}{l}0 \text { to } 0.8 \\
0.6 \text { to } 2 \cdot 1 \\
0.1 \text { to } 1.2 \\
1.1 \text { to } 4.8\end{array}$ \\
\hline $\begin{array}{l}\alpha \text {-D-Galactosidase } \\
\text { Serum } \\
\text { Day } 0 \text { to } 7 \\
\text { Day } 13 \text { to } 15 \\
\text { Day } 19 \text { to } 21\end{array}$ & $\begin{array}{l}4 \\
7 \\
7 \\
3\end{array}$ & $\begin{array}{l}0 \cdot 3 \\
1 \cdot 9 \\
2 \cdot 7 \\
6 \cdot 4\end{array}$ & $\begin{array}{l}0.1 \text { to } 0.6 \\
1.1 \text { to } 3.2 \\
1.6 \text { to } 4.6 \\
2.8 \text { to } 14.5\end{array}$ \\
\hline $\begin{array}{l}\beta \text {-D-Galactosidase } \\
\text { Serum } \\
\text { Day } 0 \text { to } 3 \\
\text { Day } 5 \text { to } 7 \\
\text { Day } 13 \text { to } 15 \\
\text { Day } 19 \text { to } 21\end{array}$ & $\begin{array}{l}5 \\
3 \\
6 \\
6 \\
3\end{array}$ & $\begin{array}{r}0 \cdot 3 \\
5 \cdot 3 \\
6 \cdot 7 \\
20 \cdot 9 \\
32 \cdot 5\end{array}$ & $\begin{array}{c}0.1 \text { to } 0.4 \\
2.9 \text { to } 9.7 \\
4.4 \text { to } 10.2 \\
13.7 \text { to } 32.0 \\
17.8 \text { to } 59.2\end{array}$ \\
\hline $\begin{array}{l}\alpha \text {-D-Glucosidase } \\
\text { Serum } \\
\text { Day } 0 \text { to } 3 \\
\text { Day } 5 \text { to } 7 \\
\text { Day } 13 \text { to } 15 \\
\text { Day } 19 \text { to } 21\end{array}$ & $\begin{array}{l}6 \\
2 \\
6 \\
9 \\
2\end{array}$ & $\begin{array}{l}1 \cdot 3 \\
4 \\
3 \\
11 \\
19\end{array}$ & $\begin{array}{l}0.7 \text { to } 2 \cdot 2 \\
2 \text { to } 11 \\
2 \text { to } 5 \\
7 \text { to } 17 \\
7 \text { to } 51\end{array}$ \\
\hline $\begin{array}{l}\beta \text {-D-Glucosidase } \\
\text { Serum to } 7 \\
\text { Day } 0 \text { to } \\
\text { Day } 13 \text { to } 15 \\
\text { Day } 19 \text { to } 21\end{array}$ & $\begin{array}{l}4 \\
8 \\
2 \\
3\end{array}$ & $\begin{array}{l}0 \cdot 3 \\
1 \cdot 6 \\
1 \cdot 3 \\
3 \cdot 4\end{array}$ & $\begin{array}{r}0.1 \text { to } 0.5 \\
0.7 \text { to } 2 \cdot 8 \\
0 \text { to } 4.1 \\
1.3 \text { to } 7.5\end{array}$ \\
\hline $\begin{array}{l}\alpha \text {-N-acetylgalactosaminidase } \\
\text { Serum } \\
\text { Day } 0 \text { to } 3 \\
\text { Day } 5 \text { to } 7 \\
\text { Day } 13 \text { to } 15 \\
\text { Day } 19 \text { to } 21\end{array}$ & $\begin{array}{r}4 \\
5 \\
10 \\
9 \\
4\end{array}$ & $\begin{array}{l}1 \cdot 6 \\
48 \\
66 \\
147 \\
220\end{array}$ & $\begin{array}{l}0.4 \text { to } 3.7 \\
15 \text { to } 147 \\
30 \text { to } 144 \\
64 \text { to } 336 \\
64 \text { to } 757\end{array}$ \\
\hline $\begin{array}{l}\beta \text {-N-acetylglucosaminidase } \\
\text { Serum } \\
\text { Day } 0 \text { to } 3 \\
\text { Day } 5 \text { to } 7 \\
\text { Day } 13 \text { to } 15 \\
\text { Day } 19 \text { to } 21\end{array}$ & $\begin{array}{r}5 \\
5 \\
10 \\
10 \\
4\end{array}$ & $\begin{array}{r}6 \\
299 \\
299 \\
1212 \\
1998\end{array}$ & $\begin{array}{l}3 \text { to } 12 \\
139 \text { to } 642 \\
174 \text { to } 513 \\
106 \text { to } 2080 \\
851 \text { to } 4693\end{array}$ \\
\hline $\begin{array}{l}\alpha \text {-D-Mannosidase } \\
\text { Serum } \\
\text { Day } 0 \text { to } 3 \\
\text { Day } 5 \text { to } 7 \\
\text { Day } 13 \text { to } 15 \\
\text { Day } 19 \text { to } 21\end{array}$ & $\begin{array}{l}3 \\
3 \\
7 \\
5 \\
2\end{array}$ & $\begin{array}{l}1 \cdot 1 \\
1.2 \\
0 \cdot 8 \\
1 \cdot 2 \\
1 \cdot 6\end{array}$ & $\begin{array}{l}0 \text { to } 4.2 \\
0.2 \text { to } 2.7 \\
0.2 \text { to } 1.6 \\
0.5 \text { to } 2.4 \\
0.9 \text { to } 2.6\end{array}$ \\
\hline $\begin{array}{l}\boldsymbol{\beta} \text {-D-Mannosidase } \\
\text { Serum } \\
\text { Day } 0 \text { to } 7 \\
\text { Day } 13 \text { to } 15 \\
\text { Day } 19 \text { to } 21\end{array}$ & $\begin{array}{l}3 \\
7 \\
4 \\
2\end{array}$ & $\begin{array}{l}0.2 \\
1.4 \\
0.9 \\
2 \cdot 4\end{array}$ & $\begin{array}{l}0 \text { to } 0.7 \\
0.7 \text { to } 2.3 \\
0.3 \text { to } 2.0 \\
0.8 \text { to } 5.4\end{array}$ \\
\hline
\end{tabular}

* The serum was taken from three to six different cows, at least one of which was at Day 14 and another was at Day 19 of pregnancy. 
time but this did not become significant until the 19 to 21 -day period $(P<0 \cdot 05)$.

$\beta$-D-Glucosidase. The assay levels in all the uterine fluid samples were elevated compared with those in serum, but there was no significant difference within the different groups.

$\alpha-\mathcal{N}$-acetylgalactosaminidase. The assay levels in all the uterine fluid samples were greatly elevated compared with those in serum. Although the means of the time groups appeared to show an increase with time, this was not statistically significant.

$\beta$ - $\mathcal{N}$-acetylglucosaminidase. The assay levels in all the uterine fluid samples were greatly elevated compared with those in serum. Within the time groups, there was a significant increase $(P<0 \cdot 01)$ after 5 to 7 days of pregnancy which continued into the 19 to 21-day stage.

$\alpha-D-M a n n o s i d a s e$. There was no significant difference between the assay levels for the individual time groups and those in serum.

$\beta$-D-Mannosidase. The assay levels for all the time groups of the uterine fluid proteins were significantly higher than those in serum but there was no significant difference between the individual time groups.

Examination of the uterine washings from five unmated cows which were slaughtered between 12 and 18 days after oestrus revealed that the glycosidase levels were similar to those found in cows at 13 to 15 days of pregnancy. However, one unmated cow slaughtered 19 days after oestrus contained much lower levels of glycosidase in the uterine washings and two cows slaughtered 20 days after infertile mating also contained lower levels of glycosidase, the values being similar to those of pregnant cows in the 0 to 3-day time group.

Glycosidase assays on rabbit uterine proteins (Table 2) revealed that the levels of some glycosidases in the uterine luminal fluid of 5- and 7-day-pregnant rabbits were very much higher than in non-pregnant rabbits or in serum. The levels of $\alpha$-L-fucosidase, $\beta$-D-galactosidase, and $\beta$-D-glucosidase were very much increased in the uterine proteins from the pregnant animal; those of $\alpha$-Dglucosidase, $\alpha$-D-mannosidase and $\beta$-N-acetylglycosaminidase were increased to a lesser extent.

No significant neuraminidase activity was detected in bovine uterine proteins from cows in oestrus and various stages of pregnancy up to 35 days. Under the assay conditions used, the colour produced at $549 \mathrm{~nm}$ after correcting for the absorption at $532 \mathrm{~nm}$ corresponded to less than $2 \%$ release of the available sialic acid in ovine submaxillary gland glycoprotein. Bovine serum under similar assay conditions gave rise to a small release of sialic acid.

\section{Trypsin and antitrypsin-like activities}

No significant trypsin-like activity was detected by either assay method at $\mathrm{pH} 7 \cdot 6$. Three samples were examined at $\mathrm{pH} 4.0$ but no activity was detected. A further sample was examined at $0.5 \mathrm{pH}$ unit intervals between $\mathrm{pH} 3$ and 8 without any trypsin-like activity being found.

The uterine fluid proteins did contain antitrypsin activity, the amount of activity in the proteins isolated from cows at oestrus being similar to that in serum. Uterine fluid proteins from pregnant cows contained only about $50 \%$ or less of the activity of serum. 
Table 2. Glycosidase activities of proteins from the uterine luminal fluid of the pregnant rabbit

\begin{tabular}{|c|c|c|c|c|}
\hline \multirow{3}{*}{ Glycosidases } & \multicolumn{4}{|c|}{ Enzymatic activities ( $\mu g$ p-nitrophenol released/mg protein $/ 3 \mathrm{hr}$ ) } \\
\hline & \multirow{2}{*}{ Serum* } & \multicolumn{3}{|c|}{ Uterine fluid } \\
\hline & & Non-pregnant & Pregnant (Day 5) & Pregnant (Day 7) \\
\hline $\begin{array}{l}\alpha-\mathrm{L}-\text { Fucosidase } \\
\beta-\text {-Fucosidase } \\
\alpha-\mathrm{D}-\mathrm{Galactosidase} \\
\beta \text {-D-Galactosidase } \\
\alpha-\mathrm{D}-\text { Glucosidase } \\
\beta \text {-D-Glucosidase } \\
\alpha \text {-D-Mannosidase } \\
\beta \text {-D-Mannosidase } \\
\alpha-\mathrm{N} \text {-acetylgalactosaminidase } \\
\beta \text {-N-acetylglucosaminidase }\end{array}$ & $\begin{array}{l}7 \cdot 5 \\
0 \cdot 2 \\
0 \\
0 \cdot 2 \\
0 \\
0 \\
2 \cdot 4 \\
0 \cdot 1 \\
0 \cdot 5 \\
3 \cdot 3\end{array}$ & $\begin{array}{r}6 \cdot 4 \\
1.9 \\
1 \cdot 0 \\
3 \cdot 1 \\
0 \cdot 4 \\
2 \cdot 6 \\
3 \cdot 8 \\
1 \cdot 0 \\
3 \cdot 3 \\
17\end{array}$ & $\begin{array}{c}1025 \\
1 \cdot 3 \\
6 \cdot 6 \\
333 \\
4 \cdot 1 \\
226 \\
27 \cdot 8 \\
2 \cdot 1 \\
0 \cdot 3 \\
92\end{array}$ & $\begin{array}{c}1017 \\
0 \cdot 9 \\
1 \cdot 1 \\
181 \\
3 \cdot 1 \\
167 \\
22 \cdot 6 \\
0 \cdot 8 \\
1 \cdot 8 \\
130\end{array}$ \\
\hline
\end{tabular}

* Arithmetic mean of activity in the serum from one rabbit at Day 5 and Day 7 of pregnancy.

\section{Hormone-binding activity}

The uterine fluid proteins showed only very low binding of oestradiol and progesterone, the levels not being significantly different from those of serum treated similarly. By contrast, rabbit blastokinin, isolated as described by Krishnan \& Daniel (1967), bound progesterone strongly under these conditions.

\section{DISGUSSION}

In previous studies, peptidase has been detected in the uterine fluid from rats and rabbits near oestrus (Albers, Bedford \& Chang, 1961), protease activity has been detected in rabbit uterine secretions $24 \mathrm{hr}$ before implantation (Kirchner, Hirschhäuser \& Kionke, 1971), neuraminidase in rabbit uterine secretion (Schwick, 1965), and $\beta$-amylase in rabbit uterine secretion (Kirton \& Hafs, 1965). It has been suggested that these enzymes may be involved in the process of sperm capacitation (Kirton \& Hafs, 1965), implantation (Albers et al., 1961) or dissolution of the zona pellucida (Kirchner et al., 1971). In the present investigation on the enzymatic activity of uterine secretions in the cow, it was decided to concentrate mainly on enzymes that might modify glycoprotein or glycolipid structures since carbohydrate-containing material is prominent in the zona pellucida of mammalian eggs (Jeanloz, 1971) and most cell surface membranes (Winzler, 1972).

It has been shown that, in certain cells undergoing rapid division, e.g. tumour cells, the structures of these glycosubstances are altered (Hakomori \& Murakami, 1968; Glick \& Buck, 1973; Dabelsteen \& Pindborg, 1973). It is not known whether this is a consequence of the rapid growth or whether the modified structure of these glycosubstances is a primary cause of the rapid growth, possibly by altering contact inhibition of cells (Burger \& Noonan, 1970 ) or the membrane permeability, thus allowing entry of important metabolites (Holley, 1972). If the latter is the case, then the presence of these glycosidases in the luminal fluid of the uterus may be important in the control of early embryonic development. 
It is also possible that these glycosidases could play an important part as initiators of the adhesive phase (Böving, 1963) of implantation. A recent theory of Roseman and co-workers (Roseman, 1970; Roth, McGuire \& Roseman, 1971; McGuire, 1972) has implicated cell surface glycoprotein in specific cell adhesion. According to this theory, specific cell adhesion occurs as an enzymesubstrate complex between sugar transferase on one cell surface and glycoprotein acceptors on another cell. Sugar transferases have a fairly strict specificity for particular acceptor non-reducing sugar end-groups on oligosaccharide chains of glycoproteins (Roseman, 1970). Hence, a specificity of cell adhesion is introduced depending on whether these sugar end-groups are available and which sugar transferases are synthesized. In the luminal fluid of the uterus, the glycosidases described in this paper would remove terminal sugars from glycoproteins on the cell surface of the trophoblast (or endometrium), thus uncovering sugars which can act as substrates for sugar transferases produced on the cell surface of the endometrium (or trophoblast). In this way, if Roseman is correct, adhesion would be initiated. It is of interest that an implantation initiator has been reported to be present in the luminal fluid of the mouse uterus (Mintz, 1971) and that changes in the cell-surface glycoproteins of mouse embryos before implantation have recently been detected (Pinsker \& Mintz, 1973). In the cow, implantation does not take place until 30 days or later (Melton, Berry \& Butler, 1951) and appears to be a gradual process. The increase in activities of some of the glycosidases during early pregnancy observed in this investigation may be required so that sufficient enzyme activity is released to uncover enough sites for a firm adhesion to take place. The small laboratory animals, such as mouse, rat or rabbit, have a much better defined time of implantation and consequently may be better models to test the relationship between glycosidase activity and implantation. Preliminary investigations (Table 2) have revealed that glycosidases are released in the uterine fluid of pregnant rabbits in much greater amounts than in the non-pregnant animal, the glycosidase activity in which was similar to serum. The rabbit differed from the cow in that $\alpha-L-$ fucosidase was the most important enzyme in the uterine luminal fluid of the pregnant animal and there was little $\beta$ - $\mathrm{N}$-acetylgalactosaminidase activity. Implantation in the rabbit is reported to start on the 7 th day post coitum and it might be expected that if the glycosidases were implicated in an adhesive phase of implantation they should appear 1 or 2 days before this so that that the reactions of sugar cleavage followed by enzymesubstrate complex formation between two cells could take place.

In this study, there was insufficient material available to determine the $\mathrm{pH}$ optima of all the glycosidases assayed and consequently a standardized $\mathrm{pH}$ of 5 was employed for all the glycosidase estimations. For comparison of the activities in uterine washings at different stages of pregnancy, this is quite adequate but in later work for which material has become available for determination of the $\mathrm{pH}$ optima of some of the most active enzymes, it has been found that this is not the $\mathrm{pH}$ optima of all the enzymes, $\alpha$-L-fucosidase and $\beta$-N-acetylglucosaminidase having $\mathrm{pH}$ optima at $\mathrm{pH} 6.0$ and 5.5 , respectively.

In the uterus the $\mathrm{pH}$ may be quite different from this, however, and although knowledge of the $\mathrm{pH}$ of the microenvironment around the developing embryo 
is not available, the $\mathrm{pH}$ of the bovine uterine fluid has been reported to be $7 \cdot 1$ (Olds \& VanDemark, 1957). At $\mathrm{pH} 7 \cdot 1, \alpha-\mathrm{L}$-fucosidase and $\beta$-Nacetylglucosaminidase retain $47.5 \%$ and $18.6 \%$, respectively, of their activities at $\mathrm{pH} 5 \cdot 0$. Another uncertainty in evaluating the importance of these glycosidases is that the substrates used for these assays were synthetic substrates and the activities of the glycosidases may be different towards their natural substrates.

The nature of the enzymatic activities detected suggest that they may be lysosomal enzymes but their origin poses some problems. Lysosomal enzymes such as $\beta$-glucuronidase (Parr, 1969) and lysozyme (Parr, Schaedler \& Hirsch, 1967) have been reported to be released into the uterine lumen of the rat during chronic leucocyte infiltration under the influence of intrauterine foreign bodies, but the concentration of leucocytes in the uterine lumen during a normal pregnancy does not appear to increase and would probably be detrimental to the pregnancy if it did. There is a possibility, however, that preferential release of certain lysosomal enzymes may occur from endometrial cells under the action of progesterone which is reported to decrease the stability of the lysosomal membrane (Weissman, 1969). It is of interest that a marked rise in the level of a lysosomal enzyme, $\beta$-glucuronidase, has been observed in the endometrial tissue of rats before implantation (Prahlad, 1962).

\section{ACKNOWLEDGMENTS}

We gratefully acknowledge the support of the Population Council, Rockefeller University, New York. We are indebted to Dr R. A. Gibbons and Dr J. M. Payne for their encouragement and advice during this investigation and for helpful criticism of the manuscript. Mr A. J. Stark kindly carried out the statistical analysis of our results and $\mathrm{Mr}$ S. Dixon prepared the ovine submaxillary gland glycoprotein.

\section{REFERENCES}

Albers, H. J., Bedford, J. M. \& Ghang, M. G. (1961) Uterine peptidase activity in the rat and rabbit during pseudopregnancy. Am. F. Physiol. 201, 554.

ANDERer, F. A. \& Hoernte, S. (1968) Chemical studies on kallikrein inactivator from bovine lung and parotid gland. Ann. N.Y. Acad. Sci. 146, 381.

Böving. B. G. (1963) Implantation mechanisms. In Mechanisms Concerned with Conception, p. 321. Ed. C, G. Hartman. Pergamon Press, New York.

Bray, G. A. (1960) A simple efficient liquid scintillator for counting aqueous solutions in a liquid scintillation counter. Analyt. Biochem. 1, 279.

Burger, M. M. \& Noonan, K. D. (1970) Restoration of normal growth by covering of agglutinin sites on tumour cell surface. Nature, Lond. 228, 512.

CoRker, C. S. \& ExLEY, D. (1970) The determination of plasma oestradiol-17 $\beta$ by competitive protein binding radioassay. Steroids, 15,469 .

Dabelsteen, E. \& Pindborg, J. J. (1973) Loss of epithelial blood group substance A in carcinomas. Acta path. microbiol. scand. A81, 435.

Gurck, M. G. \& Buck, G. A. (1973) Glycoproteins from the surface of metaphase cells. Biochemistry, 12, 85.

HAKOMORI, S. I. \& MURAKAMI, W. T. (1968) Glycolipids of hamster fibroblasts and derived malignant$\mathrm{t}$ ansformed lines. Proc. natn. Acad. Sci. U.S.A. 59, 254.

Hetmfr, R. \& Meyer, K. (1956) Studies on the sialic acid of submaxillary mucoid. Proc. natn. Acad. Sci. U.S.A. 42, 726.

Holley, R. W. (1972) A unifying hypothesis concerning the nature of malignant growth. Proc. natn. Acad. Sci. U.S.A. 69, 2840. 
JEANLOz, R. W. (197I) The chemistry of complex carbohydrates related to blastocyst composition. In The Biology of the Blastocyst, p. 131. Ed. R. J. Blandau. University of Chicago Press, Ghicago and London.

KIRChner, C., Hirschhäuser, C. \& Kionke, M. (1971) Protease activity in rabbit uterine secretion 24 hours before implantation. F. Reprod. Fert. 27, 259.

KIRTON, K. T. \& HAFs, H. D. (1965) Sperm capacitation by uterine fluid or beta amylase in vitro. Science, N.Y. 150, 618.

Krishnan, R. S. \& Daniel, J. G. (1967) "Blastokinin": inducer and regulator of blastocyst development in the rabbit uterus. Science, $\mathcal{N}, Y, 158,490$.

McGuire, E. J. (1972) A possible role for carbohydrates in cell-cell adhesion. In Membrane Research, p. 347. Ed. G. F. Fox. Academic Press, New York.

Melton, A. A., Berry, R. O. \& Butler, O. D. (1951) The interval between the time of ovulation and attachment of the bovine embryo. F. Anim. Sci. 10, 993.

Mintz, B. (1971) Control of embryo implantation and survival. Adv. Biosci. 6, 317.

Olds, D. \& VanDemark, N. L. (1957) Composition of luminal fluids in bovine female genitalia. Fert. Steril. 8, 345 .

ParR, E. L. (1969) Intrauterine foreign bodies: a toxic effect of leukocyte extracts on rat morulae in vitro. Biol. Reprod. 1, 1.

Parr, E. L., Schaedler, R. W. \& Hirsch, J. G. (1967) The relationship of polymorphonuclear leukocytes to infertility in uteri containing foreign bodies. J. exp. Med. 126, 523 .

Pinsker, M. C. \& MinTz, B. (1973) Changes in cell-surface glycoproteins of mouse embryos before implantation. Proc. natn. Acad. Sci. U.S.A. 70, 1645.

Prahlad, K. V. (1962) A study of rat uterine $\beta$-glucuronidase prior to the implantation of the ovum. Acta endocr., Copenh. 39, 407.

Roberts, G. P. \& Parker, J. M. (1974) Macromolecular components of the luminal fluid from the bovine uterus. F. Reprod. Fert. 40, 291.

Roseman, S. (1970) The synthesis of complex carbohydrates by multiglycosyltransferase systems and their potential function in intercellular adhesion. Chem. \& Phys. Lipids, 5, 270.

Roth, S., McGutre, E. J. \& Roseman, S. (1971) Evidence for cell-surface glycosyltransferases. Their potential role in cellular recognition. 7. Cell Biol. 51, 536.

Rowson, L. E. A., Lawson, R. A. S., Moor, R. M. \& Baker, A. A. (1972) Egg transfer in the cow: synchronization requirements. F. Reprod. Fert. $28,427$.

SchWERT, G. W. \& TAKENAKA, Y. (1955) A spectrophotometric determination of trypsin and chymotrypsin. Biochim. biophys. Acta, 16, 570 .

Schwick, H. G. (1965) Chemische-entwicklungsphysiologische Beziehungen von Uterus zu Blastocyste des Kaninchens (Oryctolagus cuniculus). Willhelm Roux Arch. EntwMech. Org. 156, 283.

Steel, R. G. D. \& Torrie, J. H. (1960) Principles and Procedures of Statistics, p. 157. McGraw-Hill, London.

Warren, L. (1959) The thiobarbituric acid assay of sialic acids. F. biol. Chem. 234, 1971.

Weissman, G. (1969) The effects of steroids and drugs on lysosomes. In Lysosomes in Biology and Pathology, Vol. 1, p. 276. Eds. J. T. Dingle and H. B. Fell. North Holland, Amsterdam.

WinzLer, R. J. (1972) Glycoproteins of plasma membranes. Chemistry and function. In Glycoproteins. Their composition, structure and function. Vol. 5, Part B, p. 1268. Ed. A. Gottschalk. Elsevier Publishing Co., Amsterdam. 